РОЗДІЛ 3 ТЮРКСЬКІ МОВИ

УДК $81-13$

DOI https://doi.org/10.32782/tps2663-4880/2020.13-1.30

\title{
FUNCTIONS OF INTRODUCTORY CONSTRUCTIONS IN THE LITERARY TEXT IN AZERBAIJAN LANGUAGE
}

\author{
ФУНКЦІЇ ВСТАВНИХ КОНСТРУКЦІЙ В ХУДОЖНЬОМУ ТЕКСТІ \\ АЗЕРБАЙДЖАНСЬКОЮ МОВОЮ
}

\author{
Isayeva $\mathbf{R}$. \\ orcid.org/0000-0003-2668-5602 \\ PhD Student at the Chair of Teaching Methods of Azerbaijani Language and Literature \\ Baku State University
}

In the article is noted the main features of use of introductory constructions in the literary text are considered. Material of the research was works of the Azerbaijan literary prose and of the 20-30-s years of the XX century and texts of modern Azerbaijan literature of the last decades. In the work the most characteristic functions of introductions, their connection with various informative levels (within the sentence and the text in whole), a role in the general structure of the literary text are defined. A classification of introductory constructions depending on domination in them of a certain type of information (introductions of the informative and emotional and expressional, estimated character) is presented. Special attention is paid to the diversity of these syntactic means and their role in the realization of writer's artistic intention. Very diversified are the functions of inserted constructions which concretize the conception of an object, personage, action and serve to transfer expression and evaluation. They actualize the certain element of a statement, save text space. Introductory and inserted constructions also perform the specific for detective genre functions: transfer the detective's mental process, involve the reader into investigation. Informative introductory constructions are subdivided into groups depending on the way of ratio of information with the main sentence (specifying introductions which specify, concretize information of the main sentence, and complementary constructions expanding information of the main part of the statement). In the work is analysed the role of introductory constructions in formation of various levels of the text (space-time organization of the text, formation of the narrative (subject) organization of the text by means of reflection of interaction of various subject-speech plans, correlation in the text of various points of view and plans of perception, participation in formation of the author's (storyteller) image and organization of his communication with the reader, establishment of intertext communications ( an intertextual function ), creation of the comic effect). In literary Azerbaijan language, especially, in written form, introductory constructions are used quite often.

Key words: Azerbaijan language, introductory word, introductory merger, introductory sentences, literary text, parenthetic constructions, dialogizing text, space-time text organization, person-speech text levels, communication with the reader, author's subjective modality, humourous effect, intertext.

У статті зазначено основні особливості використання вставних конструкцій у літературному тексті. Матеріалом дослідження стали твори азербайджанської літературної прози 20-30-х років XX століття та тексти сучасної азербайджанської літератури останніх десятиліть. У роботі визначено найбільш характерні функції вступів, їх зв'язок з різними інформативними рівнями (усередині речення та тексту в цілому), роль у загальній структурі літературного тексту. Подано класифікацію вступних конструкцій залежно від домінування в них певного виду інформації (введення інформативно-емоційно-експресійного, оціночного характеру). Особлива увага приділяється різноманітності цих синтаксичних засобів та їх ролі у реалізації художнього задуму письменника. Дуже урізноманітненими є функції вставлених конструкцій, які конкретизують концепцію об'єкта, персони, дії та служать для передачі враження та оцінки. Вони актуалізують певний елемент заяви, економлять текстовий простір. Вступні та вставлені конструкції також виконують специфічні для детективних жанрів функції, наприклад, передають розумовий процес детектива, залучають читача до розслідування. Інформативні вступні конструкції поділяються на групи залежно від способу співвідношення інформації з головним реченням (із зазначенням вступів, які конкретизують інформацію головного речення та допоміжні конструкції, що розширюють інформацію про основну частину висловлювання). У роботі проаналізовано роль вступних конструкцій у формуванні різних рівнів тексту (просторово-часова організація тексту, формування наративної (тематичної) організації тексту за допомогою відображення взаємодії різних предметномовленнєвих планів, співвідношення в тексті різних точок зору та планів сприйняття, участь у формуванні образу автора (розповідача) та організація його спілкування з читачем, встановлення міжтекстових комунікацій (інтертекстуальна функція), створення комічного ефекту). У літературній азербайджанській мові, особливо в письмовій формі, вступні конструкції використовуються досить часто.

Ключові слова: азербайджанська мова, вступне слово, вступне злиття, вступні речення, літературний текст, душевні конструкції, діалогізуючий текст, організація тексту простору-часу, особистісно-мовленнєвий рівень тексту, спілкування з читачем, суб'єктивна модальність автора, гумористичний ефрект, інтертекст. 
Introduction. From the second half of the twentieth century in the syntax section of linguistics there has been a fundamental transformation. The basis of this transformation was based on theories "dependence grammar" by L. Tenyer of and "creative aspect of language" by N. Khomsky. N. Khomsky's derivative grammar is known as the "Khomsky Revolution" and, therefore, derivative linguistics in the United States is at the forefront. Problems of syntax in Turkology and Azerbaijani linguistics have been studied by various linguists from constructive, semantic, pragmatic, formal and functional aspects. Unlike phonetics, vocabulary, and morphology, syntax consists of constructive units that are not readily available in the language, each time reconstructed in a speech act. Contemporary literary texts consist of a variety of colorful structures in terms of syntactic structure. Additional constructions may include sound, letter or syllable, missed initial meanings, epenthesis, question and exclamation words, words, syntactic units, word combinations, sentences, fragments that form part of the main sentence, and syntactic constructions between independent sentences. Introductory constructions contains additional notes and explanations that complement and explain the specific meaning of the main sentence. Introductory constructions severely disrupt the logical and grammatical relations between members of the sentences they contain. The meaning they express gives additional meaning to the main meaning of the sentence in the second, less important or vice versa, which is not specifically mentioned in the first place. It should be noted that additional words and additional sentences were, for some reason, interspersed with intermediate words and phrases, which, as a fact of speech, were not concealed, to some extent, to one or another level. Unlike simple words and phrases that express modality, word combinations are described as subjective views of the person who makes introductory constructions in the form of simple and complex sentences and enriches the meaning of the sentence.

Analysis of recent research and publications. In Azerbaijani linguistics, introductory constructions are widely used in written and spoken language. The additional lexical and syntactic units used within the sentence are semantically diverse. It is possible to expand, shorten, restrict, or limit the expression expressed by introductory constructions, to explain one or more of the words, expressions, and terms used, to describe the mimicry and gestures of the speech, and to provide information about time, space, and current situation.
Introductory constructions come in a different structure.

a) Introductory constructions consists of one word: Future commanders (captains) of the army are listening carefully to my lesson.

B) Introductory constructions consists of word combinations: Today, Aygun (cousine) is coming from Moscow with her friends.

c) Introductory constructions consists of sentences: By the way, because of Gadiyev's misfortune, or the happiness of the design engineer, the way of Wazirbeyli came to Bayil (Verdiyev then assured Gaddiyev that Vazirbeyli did not have time, received hundreds of manat per hour, and did not come to Bayil himself. Someone brought him.). Different types of sentences can be encountered in literary languages; - In the first example, an additional sentence is in the form of a double sentence and the second in the form of a single sentence. Introductory sentences can also be in the form of branch clause, generalized words that belong to the members of the sentence; How was your mother? .It's good, he will see also the Sabunchu-Balakhany-Ramana (the oil world).

d) It consists of a complex sentence; in the form of a complicated sentences, and uncomplicated sentences: When she heard the name of the Shahpalang, she looked cautious eyes at the boy whom hated him for a moment and then quickly drew her eyes. ( Her mother had instructed her that there was enchantment in the eyes of the dragon. Some people are like that. The best thing is to keep your eyes out of their eyes!).

Objectives. Introductory constructions are sometimes attached to the main sentence through different connectors (or, that, because, only): This feeling was very strong in his heart (but great enthusiasm and great ideals forced a man not to listen to that emotion, to do "stupid" things in his heart), and he repeatedly tried it in practice. Only one person (who is also a relative of the bride, by the way) played beautifully, even the singers were amazed. In the first of the examples we have considered above the additional sentence associated the main sentence with the contrasting conjunction, in the second sentence, it is closed with attendance conjunction.

To connect between additional sentences and the main sentence in addition to some conjunctions, auxiliary words are also used; A young man sitting face to face with Khosrov pulling his hand to his soft hair (I mean, he put a little oil on his hair) and said looking with regret look at unknown point at the unfamiliar.

d) It consists of syntactic total:

You see, a hundred-year-old earthy roof

Turns into palace in a month... 
Looks and believes a man in his eyes

The dawn rises in the house perfectly,

Envy him the star and the moon ...

(My goal is not philosophy, friends!

What I write I see with my eyes.

Let me keep this style on behalf of me -

I say with my saz and with my words,

What I write I see with my eyes).

Discussion (Presenting main material)

The position of additional words and additional sentences is measured by the speech text. Beyond the text, there is no additional vocabulary and no additional sentence $[5$, p. 100]. Both the additional words and the additional sentences occupy a secondary position in the speech. They are not independent in the background of the text, they are assistants. Without them, the text of the speech is formed and the speech is completed. Additional lexical and syntactic units may not be as related to the contents of a sentence as they are used within or after the main sentence. When it comes to the content of a sentence, along with referring to a whole sentence, it also may be part of a sentence or a sentence member. Example: I tell you now, my brother Farda, I say to you, my brothers (he has grown up a little and reviewed patriots), yes, I tell you .And now I'll put you down (The sound changes). Farhad was a mighty artist who studied in Khata, China. In the first example, the addition is entirely related to the contents of the sentence, in the second sentence to the part of the sentence, and in the third sentence to one member of the sentence.

Introductory constructions are less commonly used in oral speech. During pronunciation, they are separated from the main part of the text by intonation and have a lower tone. In the written speech, however, this separation is indicated by brackets on both sides and sometimes with dashes on both sides. Example: Agamajid's mother, Karinja khanum (in fact, the woman's name was Masma), grabbed arm of Bahar. Students participating in the school Olympics - you already know about it - will perform tomorrow. The pronunciation and position of the words used in brackets are not the same as the position and pronunciation of words separated by a dash. Separate words from both sides of the bracket from the text and characterize them in terms of intonation.

Additional sentences, like other sentences, are units of speech that express the finished idea. However, their position in the speech differs from that of the sentences in the text [5, p. 102]. Additional sentences are not the leading parts of the speech, without which they will be informed of any event or issue. As the name implies, they add text. If we omit one or more of the main sentences that make up the text, the text may appear inconsistent and irrelevant. Although it is possible to cite an example so that one or more sentences are not reduced in the text.

Additional sentences do not serve as a direct expression of opinion, so their positions in the text are auxiliary: their reduction does not affect the structure and overall content of the text. However, these additional sentences provide additional information. This shows their importance. In general, additional words and additional sentences are essential to make generalization, specification, certain corrections and to identify non-specific ones [5, p. 104]. With the help of additional words and phrases, simple versions of terms and expressions that are unknown to the general public are given, the ideas expressed in the main part are revealed in a different way. Additional words and additional sentences assume the possibility of complicating the text, and the author creates laconics in expression, style, by transferring relatively second-order concepts, ideas to additional words and sentences.

There are other considerations in the use of additional words in the literary language, especially in additional sentences. They act as literary and artistic means and add color. Poetry leaves the story unfolding, evaluates the situation with general literary judgments, and encourages the reader to pay attention to this or that aspect, conducts proceedings according to the movement and signs of the characters. Example:

No, he wasn't going, he flew off in the sky

(I flew next to him like a bird)

In this room, you and I, my grandfather, Fuzuli

(fell ill due to parting, my grandfather, Fuzuli)

You see, a hundred-year-old earthy roof

Turns into palace in a month...

Looks and believes a man in his eyes

The dawn rises in the house perfectly,

Envy him the star and the moon ...

(My goal is not philosophy, friends!

What I write I see with my eyes.

Let me keep this style on behalf of me -

I say with my saz and with my words,

What I write I see with my eyes).

As we have seen, in the first example an additional sentence is expressed in one sentence, and in the second example, a syntactic whole. Additional sentences were used in three parts of the poem "Zəncinin arzular1" (Dreams of the Black). The poet gives a great sense that the black is silent and quiet when he comes to the chair for a speech and the expression 
of the meaning is broken by the description and added in the following sentences:

He leaned against the chair. He didn't speak, a moment of silence,

He thought in a while with gloomy eyes

(Sometimes with dump pride takes sword heroism, All the world bow before him ...)

Additional sentences are not used to provide information about the course of the poem's events. If you remove them from the work, the plot does not appear. But they are important in every way. The poems are sometimes expressed by the poet's wishes. Events are assessed, opinions on human relations are raised, and the lyricism of the poem is enhanced.

Conclusions. It is also important to note that the text may be a work of art with the use of additional words and additional sentences, as well as works with little or no additional words or phrases. As for the comparison of fiction, the facts show that the frequency of complementary constructions in the language of fiction that gives a relatively broad description of events is higher. In this sense, however, the words used in fiction, especially the additional sentences, should be learned not only in linguistic terms, even if the additional sentence in the sentence of S. Vurgun is related to the main word. This aspect is absent in other parts of the literary language [5, p. 116].

The positions and roles of additional words and sentences are so varied that it is difficult to distinguish them from certain groups. In short, impossible. Additional sentences are more likely to be explained. The additional sentence either reveals the meaning of the keyword or gives some other information about it. Example: "The script of Sabuhi by the writer Rafili (We also got acquainted with the script by A. Beknazarov, R. Tahmasib, and Y. Dukor) is very remarkable." (S. Vurgun). Although the supplementary sentence here refers to the key word, it does not serve to clarify the meaning of the word but is used for a different purpose. The additional sentence here refers to the clause of the main sentence. It provides information, in one word or another, in the main part of the additional sentence. Example: "We were waiting for our interlocutors to come to the main issue (love, love conversations are in some kind of introductory character)". As you can see, the additional sentence in this example is not meant to explain any words or phrases in the main sentence.

In the Azerbaijani literary language, especially the written form of the literary language, additional structures are worked out quite a lot, regardless of the vocabulary they have. It contains the sentence but does not exceed its boundaries.

Sentences that are structurally different are expressed in different associations when they are complementary due to the complex interplay of different constituents, causes and outcomes, movement, or replication of the speaker. The analysis of the existing factual material reveals a link between the constructive-syntactic combination of the additional elements of the sentence. When approaching a word or word combination, it is interpositive to the whole of the sentence, and in the postpositive position when it coincides with the whole sentence.

\section{REFERENCES:}

1. Abdullayev Ә.Z., Seyidov Y.M., HəsənovA.Q. MüasirAzərbaycan dili (Sintaksis), Bakı, Şərq-Qərb, 2007, 424 s.

2. Abdullayev K.M. Azərbaycan dili sintaksisinin nəzəri problemləri, Bakı-2016,

3. İbrahimov M.ə. Seçilmiş əsərləri II cilddə II c.,Bakı: Şərq-

4. Paşayev C.ə. Seçilmiş əsərləri IV cilddə II c., Bakı: Gənclik nəşriyyatı 1967, 498 s.

5. Seyidov Y.M. Azərbaycan ədəbi dilində əlavə sözlər və əlavə cümlələr, Bakı, $2000,168 \mathrm{~s}$.

6. Seyidov Y.M. Osərləri XV cilddə I c. Bakı: Bakı Universiteti nəşriyyatı, 2006, 628 s.

7. Seyidov Y.M. Qrammatik cəhətdən cümlə üzvləri ilə əlaqədar olmayan sözlər.Xitab və ara sözlər. ADU nəşri B.,1958, s.74.

8. Şirəliyev M.A., Hüseynzadə M.H. Azərbaycan dili.Sintaksis B.,1976.

9. VeysəlliF.Y.Azərbaycan dilininfunksional qrammatikası: FonemikavəMorfemikalll cilddəlc., Bakı-2014, s. 530.

10. Veysəlli F.Y., Kazımov Q.Ş.,Kazımov İ. B. , Məmmədov A.Y. Azərbaycan dilinin funksional qrammatikası: Sintaqmatika,Söz birləşməsi və sadə cümlələrin sintaksisi: IV cilddə.III c,Bakı: Prestij çap evi,2014, 505 s.

11. Акимова Г.Н. Развитие синтаксических конструкций в современном русском языке и динамика структуры современного русского языка. Ленинград, 1982. С. 85-121.

12. Аникин А.И. Соотношение вводных и вставных конструкций в современном русском языке. Русский язык. Москва, 1975. С. 19-33.

13. Аникин А.И. Функции вставных конструкций в современном русском языке. Уч. зап. МГПИ им. Ленина. Москва, 1967. № 259.

14. Валгина Н.С. Синтаксис современного русского языка. Москва, 1991. 432 с.

15. Akhmanova O. et a!. The Prosody of Speech. M. 1973.

16. Faulkner C. W. Writing Good Sentences. A functional Approach to Sentence Structure, Grammar and Punctuation. New York, 1957.

17. Parentheses, brackets, and ellipsis marks. Henry I. Christ. Modern English in Action. D.C. Heath and Company. Lexington, Massachusetts, Toronto. 1978. p. 377-378. 